From the Anat. Labor. of Prof. H. SETO, Tohoku University, Sendai.

\title{
Innervation of Vasa Umbilicalia and Proximal Adherent Part of Umbilical Cord.
}

\author{
饻動静脉及び豚带起始部の神経分布 \\ Toshiaki KONNO 今. 野 利 秋. \\ [Received February 20, 1954.]
}

The interesting problem of whether the umbilical cord is penetrated by nerve fibres has tempted many researchers to histological studies thereof, namely, by KÖLLIKER (1861), GOENNER 1906), MABUCHI (1924), STÖHR (1928), DANCZ (1931), OOI (1934) and FRITZ (1934) among many others. Most of them were inclined to affirm the existence of nerve elements in the cord, except STÖHR (1928), who alone was firm in his negation, on the strength of his observations with his reliably well-stained silver preparations.

DOGIEL (1902), TIMOFEEJEW (1902), RAMSTRÖM (1905, 1908) and CYLON (1869) have reported on their histological studies on the innervation of the ventral abdominal wall, but there are many points of doubtful accuracy in their findings. The minute studies on the subject by AZUMA (1951) of this laboratory reported recently with 10th month human embryos as material have contributed much in tht elucidation of the problem, but the umbilical cord was not touched upon in his study.

With such a situation in mind, I undertook to unravel the innervation of the inside of the umbilical cord by a systematic examination of it, at the same time to study the innervation of the ventral abdominal wall around the anulus umbilicalis. The materials I took from the umbilical cords of tenth and fourth month human embryos, with preference to their proximal part including more or less of the ventral abdominal wall, which I fixed for a long time in $10 \%$ neutral formol, cut into $40 \mu$ transverse and frontal frozen sections and stained with SETO's silver impregnation. The large series of beautifully stained preparations thus obtained I subjected to minute microscopic scrutiny and succeeded in arriving at the following results.

\section{Findings.}

\section{A. Are the vasa umbilicalia accompanied by nerve fibres ?}

KÖLLIKER (1861) has opined that the existence of nerve fibres is 
limited to the embryonic side of the umbilical cord. However, GOENNER (1906) detected a nerve running along the umbilical artery in the ventral abdominal wall as far as the anulus umbilicalis by means of a magnifying glass, but could not affirm whether it penetrated into the umbilical cord. In 1924, following CAJAL's method, MABUCHI obser. ved the existence of nerve fibres running through the umbilical cord right up to the placenta and described them as terminating freely in the tunica media of the vasa umbilicalia, but STÖHR (1928) declared them as mere artefacts. By the same method, DANCZ (1931) also reported his discovery of sympathetic nerve terminations ending freely in the vasa umbilicalia, and OOI (1934) also similarly asserted the existence of strongly developed nerve fibres and small nerve cells in the walls of the umbilical blood vessels in man and animals. ERITZ (1934) reported tha the found a sympathetic cell group alongside the adventitia of the umbilical vein at the point about $4 \mathrm{~mm}$ from the anulus umbilicalis, though in a rare case, but STÖHR alone persisted in his denial of existence of nerve elements in the umbilical cord and placenta, as lately as in the year of 1938.

Thus, the recent researchers affirm the existence of nerve fibres in the umbilical cord, especially of some nerve elements running along the vasa umbilicalia, but STÖHR (1938) is unique in his downright denial of such nerves. Now, what has impressed me most in the course of my study on the subject were the facts that, if there lurked some weakness in the most basic method of the study, or, if the staining method was not of ideal appropriateness (as when the CAJAL's method or a variation thereof was employed), the results of studies based thereon would be tainted with the same error everytime, or, in this case, nerve elements of artefact would be always discovered in the umbilical cord, while armed with the excellent and dependable silver method perfected by STÖHR, we would scarcely be deceived into finding such an artefact where no nerves exist, and, in this connection, that figures of nerves of very dubious authenticity, drawn from preparations stained with gold chloride or under CAJAL's method, which should be replaced by truer to nature figures copying excellent silver impregnated preparations now available as soon as possible, occupy unwarranted spaces in the pages of current text-books.

I used the improvement of STÖHR's silver impregnation perfected by Prof. SETO, which is in all probability even better than the original STÖHR's method. This method has the characteristic of staining the nerve elements the better, the more satisfactory the staining of the other tissues in general, so that when using this method, we may add apropos, we of all things take care to have the other common tissues stained as 
best as possible and we can depend upon the nerve elements existing therein to come out in utmost vividness.

Among the above cited studies, we may pay passing attention to those by KÖLLIKER (1861) and GOENNER (1906) regardless of the inadequacy of the staining methods they utilized, since, though I concur entirely with STÖHR (1938) in utterly denying the existence of nerve elements running into the umbilical cord proper, as detailed hereunder, I could observe the existence of minute nerve fibres in the incipient part (transitional part hereunder) of the umbilical cord.

In the course of my study, I was surprised to find that the vasa umbilicalia entering and leaving the cord are not provided with the collagenous connective tissue adventitia, which covers all the other com. mon arteries and veins in the body, accordingly lacking all formation of vegetative nerve plexus around them. To speak in detail, the other blood vessels in the body have vegetative nerve plexus formed in their adventitia without exception, and I had been led to expect some vegetative nerves accompanying the vasa umbilicalia running in the ventral abdominal wall, too, but $I$ was disappointed and found the umbilical: blood vessels unparalleled in their refusal of nerve accompaniment. These blood vessels are indeed devoid of any adventitia even before entering the umbilical cord and run, adventitialess, through the connective tissue sparsely arranged and much resembling the embryonic connective tissue. No formation of vegetative nerve plexus connected with the control of the smooth muscle fibres in the tunica media of the blood vessels is found in this connective tissue. Much the less is the chance of nerve fibres accompanying the peripheral parts of such blood vessels entering the umbilical cord.

A physiological deliberation on the peculiar structure of these blood vessels seems to lead to the conclusion that, since these vessels are unaccompanied by nerve elements, in contradistinction to the other blood vessels in the body of embryo, the blood flow through these vessels is not accomplished by the autonomic contraction of the walls of the vessels but is passively governed by the action of the nerve center controling these vessels. This lack in the contractive action of these vessels may be also deduced from the almost complete absence of elastic fibres in the media of these vessels. The lack of nerve elements along the umbilical vessels may be assumed to be of good advantage in the ultimate decease and deciduation of the umbilical cord as well as the change into connective tissue of the vessels in the abdominal wall after birth.

\section{B. Innervation of the transitional part of the umbilical cord.}

As mentioned above, I could never detect the presence of any nerve 
element in the umbilical cord proper, either in the vicinity of the artery and vein or otherwise in the embryonic connective tissue, but in the so-called incipient part of the cord alone $I$ could find a small quantity of nerve elements. This part has some similarity in histology to the umbilical cord proper, but belongs in no sense to the latter, and yet it is to be distinguished from the surrounding skin of the ventral abdominal wall. It forms a narrow disclike area marked off by astringent grooves from the abdominal wall on the one side and from the cord on the other, is approximately $5 \mathrm{~mm}$ in length in a tenth month embryo, and is destined to become the navel after birth.

The histological picture of this special part, the transitional part as I would call it, is of a curious peculiarity as described in the following. The epithelium of its outermost layer is not of the nature of the smooth surfaced single or doublerowed cubic or columnal epithelium of the amnion, but is rather similar to the epidermis of the abdominal wall. However, it is somewhat thinner than the latter and consists of squamous stratified flat epithelium. This character of the epithelium differentiates the transitional part with extreme distinctness from the umbilical cord proper and the surrounding ventral abdominal wall. Beneath the epithelium a fibrous connective tissue layer is formed, as beneath the epidermis of the abdominal wall, but the former is far inferior in development to the latter. The surroundings of the vasa umbilicalia in this transitional part is filled with embryonic connective tissue. Otherwise, it must be mentioned that some sweat glands exist here in poor development and hair roots are observable only in the part next to the abdominal wall but in no other parts as a rule. Some minute blood vessels, capillaries and lymphatic vessels are seen in this part, which is not the case with the umbilical cord proper.

Thus, the transitional part is somewhat similar to the umbilical cord but much more to the ventral abdominal wall in nature, and is destined to form the navel after birth, It is, therefore, natural that the part should be provided with small blood and lymph vessels and consequently it should be supplied with nerve fibres as in other parts of the body, especially the skin.

As for the innervation of the transitional part, the incoming nerve fibres do not accompany the vasa umbilicalia but always run alongside the small blood vessels distributed throughout the part, as in the surrounding ventral wall. The nerve elements are composed in main of non-medullated vegetative fibres but a minority is represented by much stouter sensory fibres.

The small vegetative nerve bundles run in general along the walls of the small blood vessels, with preference for small arteries, gradually 


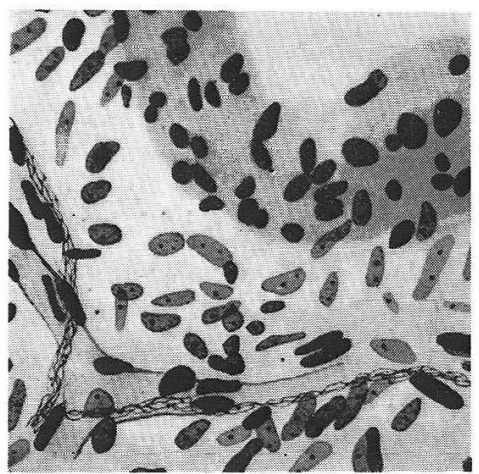

Fig. 1. Vegetative terminalreticulum running along a blood capillary in subepithelial connective tissue in the transitional part of the umbilical cord of a fourth month embryo. SETO's silver method. $\times 700$, reduced to $1 / 2$.

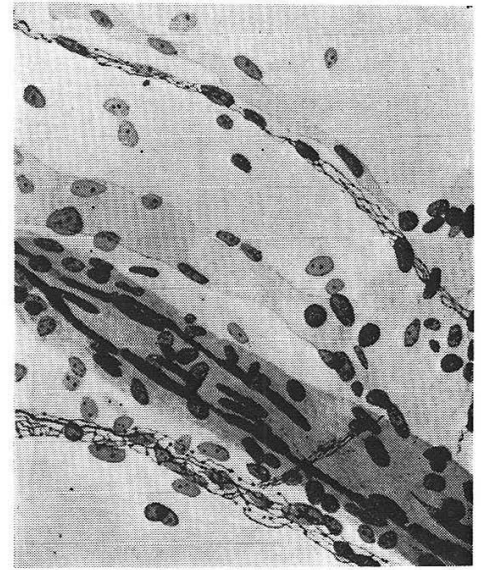

Fig. 2. Terminalreticulum running along a small artery and a small vein in the same place. Same staining. $\times 700$, reduced to $1 / 2$.

dividing into finer branches as they proceed distally, finally to pass over into the vegetative terminalreticulum, which extends chiefly in the subepithelial connective tissue. The terminalreticulum represents the terminal formation of the vegetative nerve fibres, as it has been established clearly by numerous studies since the days of STÖHR. As shown in my illustrations (Figs. 1, 2 and 5), the terminalreticulum is formed by a net-like configuration of neuro-fibrils so fine as to be further indivisible, running cord-wise and never ending freely but always coming into anastomosis with other neuro-fibril cords. Besides, also in my case, here and there, some SCHWANN's nuclei are found in the terminalreticulum.

This terminalreticulum is already in distinct formation in my fourth month embryos. Fig. 1 shows one formed along a blood capillary running in the subepithelial connective tissue in the transitional part in a fourth month embryo, Fig. 2 typical ones running along a small artery and a small vein in the same part, and Fig. 3 yet another found in the subepithelial connective tissue layer. The terminaĩreticulum always stands in supply by contact over

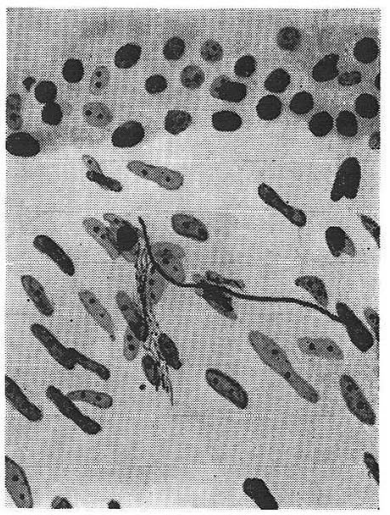

Fig. 3. Terminalreticulum and a thinner sensory fibre found in the same place of a fourth month embryo. Same staining. $\times 500$, reduced to $2 / 3$. 
all the tissue cells.

The terminalreticulum in tenth month embryos is somewhat thicker in size but in structure nothing remarkable is observed in comparison with that in fourth month embryos, as seen in the examples shown in

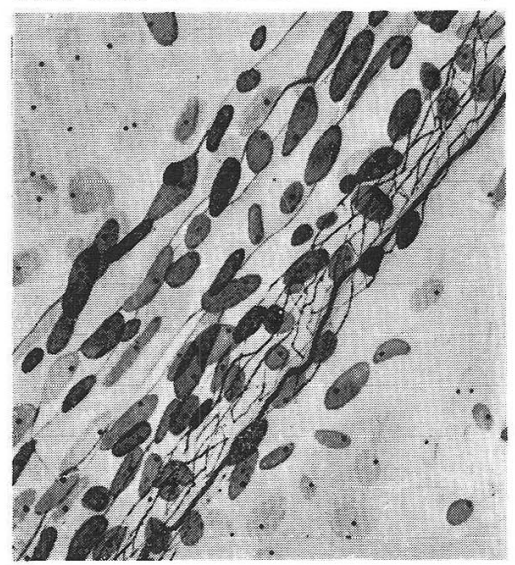

Fig. 4. Vegetative terminalreticulum accompanied by a thick sensory fibre running along the capillaries in the same place of a tenth month embryo. Same staining. $\times 700$, reduced to $1 / 2$. Figs. 4 and 5. Thus, it may be seen that the terminalreticulum attains a state of quasi-completeness by the fourth month of embryonic life, a fact endorsed by the results of the recent study on the urogenital organs of fourth month female embryos by OIKAWA (19.54) of this laboratory.

The deyelopment of sensory nerve fibres in the transitional part is very poor in tenth month embryos, to say nothing of fourth month embryos. The sensory fibres unmistakable thicker than the vegetative fibres run in company with the latter in all cases (Fig. 3 and 4), but the number of the

former is incomparably smaller, their e: istence being prover only sporadically. No branching was observed amcng them, and all my strenuous search failed in getting a clear picture of their terminal formation, but it is beyond doubt that their endings are represented as unbranched ierminatjons ending sharply.

As described above, the transitional part which is to form the navel after birth is only very poorly provided

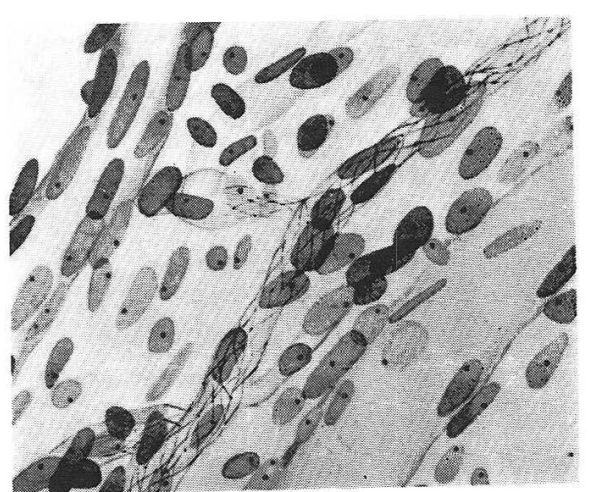

Fig. 5. Terminalreticulum formed along the blood capillaries in the same place of a tenth month embryo. Same staining. $\times 800$, reduced to $1 / 2$.

with sensory fibres in its embryonic stage, but considering the fact that it becomes rather sensitive postnatally, it may be surmised that the sensory fibres in this part come to develope rather gradually in post-natal life. 


\section{Innecvation of the ventral abbominal wall around the transitional part.}

The innervation of the ventral abdominal wall in 10 months old human embryos has been elucidated by the recent study by AKUMA (1951) in all its phases, but he failed to touch upon the same subject connected with the part surrounding the navel. The nerve fibres found in this part are derived in the main from the tenth intercostal nerve, and contain minute vegetative fibres beside the motor and sensory fibres. The vegetative fibres anastomose in places with the perivascular plexus formed in the walls of the small blood vessels, especially of the small arteries coming into this part.

The intercostal nerve fibres penetrating into the skin of this part, consist only of sensory and vegetative fibres, because of the loss of the motor fibres in the muscular layers in coming through it. The vegetative fibres run through the subcutaneous layer, form vegetative plexus in the sudoriferous layer, and then reach the papillary layer through the reticular layer of the corium, while most of the sensory fibres proceed as sensory hair nerve fibres toward the follicle necks surrounded by the sebaceous glands, finally to end in the SETO's so-called hairnerve shields or tubes therein showing the characteristic structure. The sensory terminations are represented as comparatively simple plexus-like

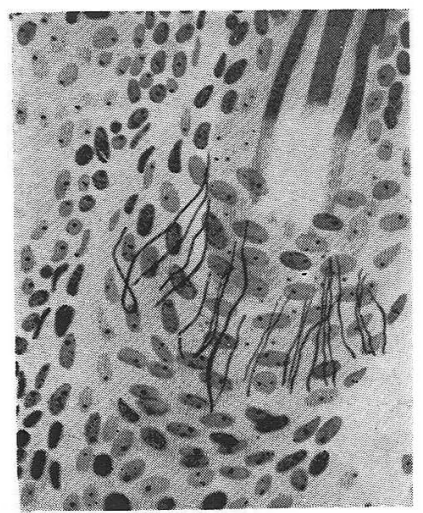

Fig. 6. A simple plexus-like sensory termination formed in a SETO's hair neuro-shield in the surroundings of the transitional part of the umbilical cord of a tenth month embryo. Same staining. $\times 600$, reduced to $2 / 3$.

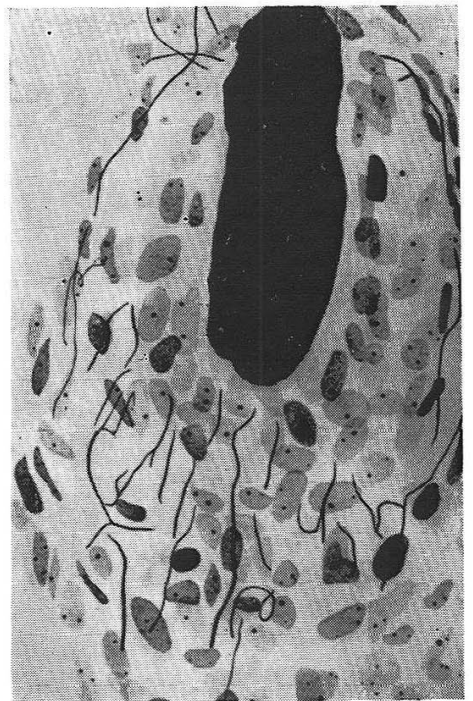

Fig. 7. A simple plexus-like termination formed in a SETO's hair neuro-tube in the same place of a tenth month embryo. Same staining. $\times 800$, reduced to $1 / 2$. 
(Figs. 6 and 7 ) or of ten as infantile non-descript terminations (Figs. 8 and 9) even in tenth month embryos.

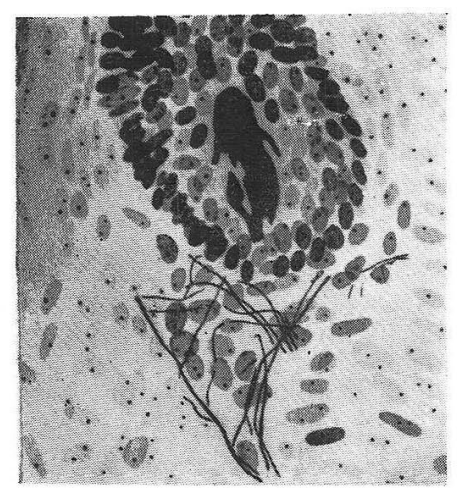

Fig. 8. An infantile non-descript sensory termination formed in a SETO's neuro-shield in the same place of a tenth month embryo. Same staining. $\times 500$, reduced to $1 / 2$.

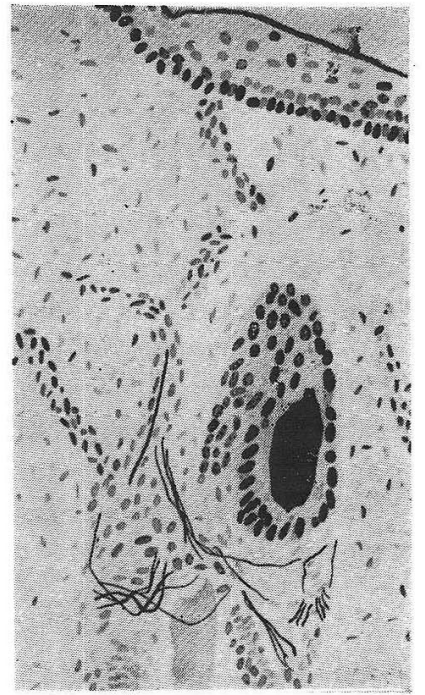

Fig. 9. Ditto. Same staining. $\times 300$, reduced to $1 / 2$.

In collation with the observations of AZUMA (1951) on the ventral abdominal wall in tenth month embryos, it may be noted that the development of sensory fibres, especially of sensory hair nerve fibres is

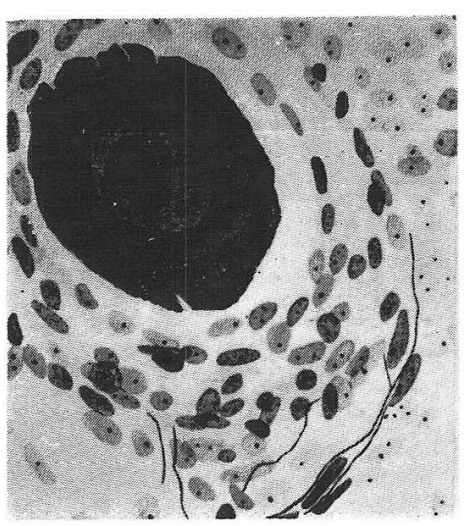

Fig. 10. A simple plexus-like termination formed in a SETO's neuro-tube in the same place of a fourth month embryo. Same staining. $\times 700$, reduced to $1 / 2$. somewhat inferior in the abdominal wall surrounding the transitional part, for in the latter part, the terminations of the sensory hair nerve fibres are limited to the infantile types of plexus-like and non-descript formations, no such comparatively complex arborized and zigzag-formed terminations as described by AZUMA (1951) being ever found. However, in $\mathrm{my}$ sections, their terminal territories are represented by the hairnerve shields and tubes in nearly equal number. This point is quite similar to the AZUMA's findings and seems to indicate that, as AZUMA has also opined, though the hairs in this part are downy in form. they 
are even more sensitive than the typical stout hairs on the head (SETO, 1942). In fourth month embryos, the development of the sensory hair-nerve terminations in the surroundings of the transitional part is incomparably infeior to that in tenth month embryos, as shown in Fig. 10.

In the papillary layer of the corium around the transitional part, vegetative nerve fibres are widely distributed together with their termination, that is, the terminalreticulum, but the sensory fibres are found very sparse, though somewhat more numerous than in the transitional part, in consonance with the observations by AZUMA (1951) on the ventral abdominal wall. These sensory fibres in this layer are derived

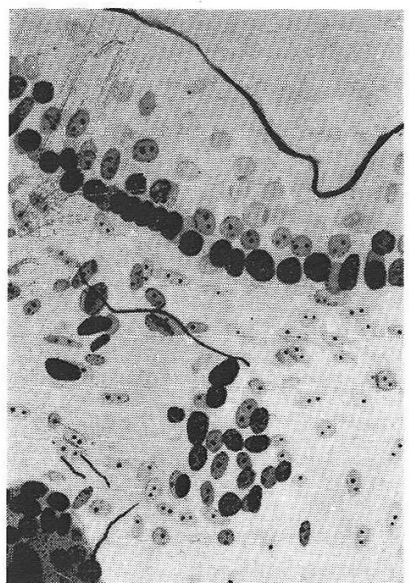

Fig. 11. Unbranched sonsory terminations found in the papillar layer in the surroundings of the transitional part of the umbilical cord of a fourth month embryo. Same staining. $\times 500$, reduced to $1 / 2$.

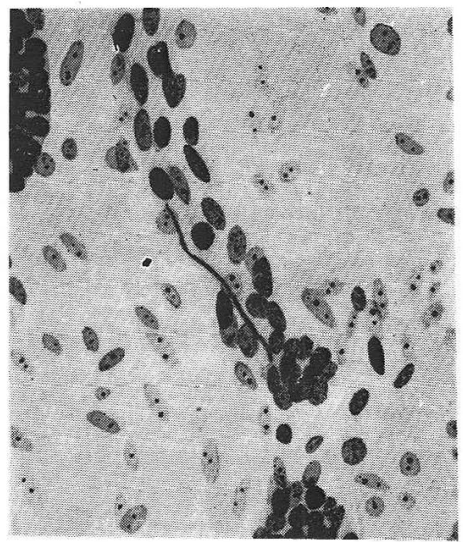

Fig. 12. An unbranched sensory termination ending bluntly in the same place of a tenth month embryo. Same staining. $\times 300$, reduced to $2 / 3$.

from the sensory hair nerve fibres and their terminations are formed very simply, namely represented by the unbranched terminations ending sharply (Fig. 11) or sometimes bluntly (Fig. 12), even in tenth month embryos.

As described above, the sensory fibres found in the papillary layer are very few in number and extremely simple in their termination, a situation quite common in the haired skin not only of embryos but also of adult beings. Namely, also in the scalp (SETO, 1942), the eye-lid (SETO, 1949), the lip (SETO and others 1950) and the mamma (SUGA, 1950), the sensory nerve fibres to the skin mostly form their terminations in the hair-nerve shields or, tubes, and only a limited number 
ends in the papillary layer and with very simple terminations. So I am inclined to believe that the sensory nerve fibres found in the papillary layer around the transitional part are also hardly destined to any noteworthy development even in post-natal life.

\section{Summary.}

If the silver impregnation is effective enough, it will be clearly seen that in the umbilical cord neither the blood vessels nor the embryonic connective tissue is provided with nerve fibres.

Even vasa umbilicalia in the ventral abdominal wall before entering the umbilical cord, are devoid of tunica externa, unlike the common blood vessels, so that no existence of perivascular nerve plexus is possible. Consequently, it must be assumed that the placental circulation through the umbilical cord is passively governed by the nerve center supplying the root parts of the vasa umbilicalia. This absence of any nerve accompanying these blood vessels may be a fortunate arrangement not only for their connective tissue closure in the abdominal wall but also for the decease and deciduation of the umbilical cord after birth.

The transitional part from the ventral abdominal wall to the umbilical cord is a mixture of both of them in histological structure; showing some resemblance with the former but more with the latter. It is covered by a thin squamous epidermis with a fibrous connective tissue layer formed subepithelially, though in a lower development than in the abdominal wall, and the space surrounding the vasa umbilicalia running through the center of this part is filled with embryonic connective tissue. Sweat glands are present, though in a weak development, and hair roots are as a rule lacking. Minute blood vessels, capillaries and lymph vessels are also found running into the part. This transitional part is about $5 \mathrm{~mm}$ in length in tenth month embryos, is marked off by astringent grooves from the umbilical cord as well as the ventral abdominal wall, and is destined to become the navel after birth.

The transitional part is supplied with nerve fibres, but not along the vasa umb!licalia nor in the embryonic connective tissue surrounding them. The nerve fibres run along the small blood vessels and are mostly of vegetative nature. Their temination spreads out as the typical terminalreticulum subepithelially already in fourth month embryos. On the contrary, sensory fibres are very small in number, and their terminations are probably represented by unbranched terminations, but I could not make out them with adequate clearness.

More nerve fibres are found in the skin of the abdominal wall around the transitional part than in the transitional part. They consist 
of sensory and vegetative fibres, the latter of which come into frequent anastomosis with the perivascular plexus, first form nerve plexus in the sudoriferous layer, then run through the reticular layer into the papillary layer. The sensory fibres, however, mostly run toward the SETO's hair-nerve shields and tubes as sensory hair-nerve fibres, to end therein. Their terminatione are represented in tenth month embryos as comparatively simple plexus-like and non-descript terminations and are inferior in development to those in the common ventral abdominal wall in the same month embryos described by AZUMA (1951). The numbers of the hair-nerve shields and tubes as the terminal territories are nearly equal in this part, so it may be assumed that the skin here is rather sensitive.

The papillary layer of the corium is well provided with vegetatire nerve fibres, but with only a very small number of sensory fibres mostly derived from sensory hair-nerve fibres. The sensory terminations are here merely represented by unbranched terminations ending sharply or sometimes bluntly, even in tenth month embryos.

\section{内容自抄。}

4 ケ月及び 10 ケ人胎兒の臍带及び其附着部の神経分布飞関する研究成 果は次の様飞要約される.

胎带内では胎動静脉周囲にも胎生結締織内にも神経の分布は見られない， 又前腹壁内を通る郮動静脉も臍带内の場合と同様, 外膜は胎生結締織から 成り, 中膜内には弾力線維を含まないから，想像された様と此所でも神経 附髄は見られなかった。 そこで此胎盤循環系の血液運行は神経司配下飞あ る臍動静脉中枢部の働きにより受動的に行われるるのと考元られる. 又此 動静脉が神経を伴わない事は生後, 前腹壁内の其結織性閉鎖にも又胎带内 の陨動静脉死滅脱落の上飞も好都合ならんと思考される.

饻带带の起始部或は移行部の形成は発生学的飞臍带と前腹壁外皮との画者 に由来する様である. 即ち此部は胎带とは多少の, 前腹壁とはより多くの 類似性を示し，上皮は䟝離性の薄い重層扁平上皮から成り，上皮下に腹 壁飞於けるよりは劣知の線維性結締織の形成を見, 中心部を通る䏽動静脉 の凮辺部は胎性結締織で満される。汗腺も発達劣勢乍ら尚招其存在を見 る. 毛根は原則的には存在しないのを一般とする。其他微細血管，血液毛 細管及び淋巴管の進入は認められる。此移行部は生後飞於て䏽部となる部 である。

放带移行部には神経の分布を見る。然し此所でも偝動静脉及び其の周囲 の胎生結締織内には神経の進入は見られない。神経は専ら小血管に伴って 
走り，其多くは植沕線維であり，其終末は既に胎生 4 ケ月に於て典型的な 植沕性終網で表わされ 專ら上皮下結締織内と拡散する。反之知覚線維は 極めて少量に存し，其終末は非分岐性最単純終末で表わされる.

弶带移行部周辺の前腹壁外皮には移行部に於けるよりは滛かに多くの神 経線維つ分布を見る．知覚線維は大多数知覚性毛髮神経として毛髮神経楯 又は管に終る。そして極めて少量の知覚線維は真皮乳頭層炕進み 甚だ単 純な非分岐性終末に移行する。此部に於ける植物神経線維の拡散は甚だ著 明であり，其終末泩こっでも植物性終綱依依り表わされる.

\section{Fe erence:}

Azuma : Tohoku J. Exp. Med. 55 (1951). P. 7. - Cylon: Arb. a. d. Physiol. Inst. Leipzig. 3 (1869). - Dancz : Z. Anat. 96 (1931). S. 543. - Dogiel : Arch. mikr. Anat. 59 (1902). - Fritz: Anat. Anz. 78 (1934). S. 79. - Goenner : Monatsschr. Gebh. u. Gyn. 24 (1906). S. 453. - Kölliker : Entwicklungsgeschichte des Menschen und der höheren Thiere. 1861. W. Engelmann, Leipzig. - Mabuchi : Mitt. Med. Facultät Univ. Tokio. (Jap.) 31 (1924). S. 455. - Oikana: In Press. Tohoku J. Exp. Med. - Ooi : Mitt. Med. Acad. Kioto. (Jap.). 10 (1934). S. 736. - Ramström : Anat H. 29. (1905). S. 349. - Ramtröm : Anat. H. 36 (1908). S. 309. 一 Seto : Arb. Anat. Inst. Sendai. 25 (1942). S. 99. - Tohoku Igaku Zassi (Jap.). 39 (1949). P. 1. - Seto, Fujii a. Ikui : No to Shinkei (Jap.). 3 (1950). P. 85. Stöhr: Möllendorffs Handbach der mikr. Anatomie des Menschen. Bd. 4, Tl. 1. 1928. J. Springer, Berlin. - Stöhr : Erg. Anat. 3 (1938). S.1. - Suga : Tohoku Igaku Zassi. (Jap.) 45 (1950). P. 327. 一 Timofeejen : Arch. mikr. Anat. 59 (1902). S. 629. 